\title{
ПОВЫШЕНИЕ ЭФФЕКТИВНОСТИ ИЗБИРАТЕЛЬНОЙ КИСЛОТНОЙ ОБРАБОТКИ СКВАЖИН ПУТЕМ ПРИМЕНЕНИЯ ТОЧЕЧНОЙ ГИДРОПЕСКОСТРУЙНОЙ ПЕРФОРАЦИИ
}

\author{
Хабибуллин Марат Яхиевич 1 , \\ m-hab@mail.ru
}

\author{
Гилаев Гани Гайсинович2, \\ gggilaev@gmail.com \\ 1 Уфимский государственный нефтяной технический университет, фрилиал в г. Октябрьский, \\ Россия, 452607, г. Октябрьский, ул. Девонская, 54 а. \\ 2 Кубанский государственный технологический университет, Институт нефти, газа и энергетики, \\ Россия, 350058, г. Краснодар, ул. Старокубанская, 88.
}

\begin{abstract}
Актуальность исследования обусловлена необходимостью обеспечивать точечное распространение кислотного раствора при проведении кислотной обработки призабойной зоны эксплуатационной скважины. Используя данный метод, повышается эфрфективность проведения данного процесса путем более глубокого растворения известняковой породы в призабойной зоне скважины и тем самым полнейшего открытия каналов для поступления пластовой жидкости из пласта в скважину.

Цель: разработать и предложить метод точечной гидропескоструйной перфорации при кислотной обработке призабойной зоны эксплуатационной скважины, методику его применения и создать конструкции подземного и наземного оборудования скважин для осуществления разработанного метода.

Объекты: лабораторный стенд с приспособлением моделирующего канал в породе; гидропескоструйный перфоратор при гидропескоструйном вскрытии; фиксатор гидравлический, предназначенный для предупреждения обрыва и снятия растягивающих напряжений в колонне труб при гидропескоструйном вскрытии и для фиксации при центровании перфоратора в заданном интервале обработки; кислотный раствор на основе соляной кислоты объемом 3-4 м³; продавочная жидкость.

Методы. Экспериментальное исследование величины давления в канале при точечной гидропескоструйной перфорации проводили на стенде. B приспособлении устанавливали насадку и штуцер определенных диаметров - $d$ и $D$ - на необходимом расстоянии между ними. Насосным агрегатом прокачивали жидкость при давлении перед насадкой р1 и фиксировали давление внутри патрубка р. В. В опытах в качестве рабочей жидкости использовали воду и водный раствор сульфит-спиртовой барды с вязкостью 12,65 сПз при температуре $20^{\circ} \mathrm{C}$. Процесс избирательной кислотной обработки состоит в том, что в скважину спускают гидропескоструйный перфоратор, устанавливая его на уровне выбранного интервала обработки, и гидравлические фиксаторы, необходимые для строгого удержания перфоратора. После этого закачивают 3-4 м $^{3}$ кислотного раствора и продавочную жидкость. Затем в насосно-компрсссорные трубы и затрубное пространство нагнетают воздух или газ (до максимального давления в распределительной будке), и в таком состоянии скважину оставляют под давлением на 20 ч, и по окончании скважину дренируют для извлечения продуктов реакции на поверхность.

Результаты. Из анализа результатов многократной (трехкратной) гидрокислотной обработки видно, что первоначальное давление закачки кислотного раствора после первого этапа обработки скважины было снижено на 24 \%, а после второго - на 55 \%. Метод кислотной обработки с дополнительной точной перфорацией призабойной зоны эксплуатационных скважин позволяет более эфффективнее проводить процесс обработки. В результате увеличивается объем притока пластовой жидкости из пласта в скважину на $20 . . .30$ \% в сравнении с обьчной кислотной обработкой.
\end{abstract}

\section{Ключевые слова:}

Канал, фильтрация, скорость, реакция, синтанол, реагент, вскрытие.

\section{Введение}

Способ точечной гидропескоструйной перфорации при кислотной обработке скважин основан на получении следующего эффекта. В выбранном пропластке или участке пласта при помощи гидропескоструйной перфорации образовывается канал, в который затем через насадку перфоратора нагнетается кислотный раствор [1-6]. Входящая в канал струя кислотного раствора препятствует выходу этого раствора из канала, как бы «запирая» его.

В результате этого в канале возникает аномальное давление, которое всегда на какую-то величину больше пластового в этой зоне и определяемое по формуле [7]:

$$
\Delta p=p_{\text {к }}-p_{\text {плл }}
$$

где $\Delta p$ - перепад давления между давлением в канале и пластовым в зоне образования канала; $p_{\text {к }}$ давление в канале; $p_{\text {пл }}$ пластовое давление в зоне образования канала.

За счет перепада $\Delta p$ кислотный раствор, находящийся в канале, фильтруется в его стенки и обрабатывает зону вокруг канала. И только часть кислотного раствора вытекает из канала в эксплуатационную колонну, попадая в другую, более дренированную зону пласта. Таким образом, этот способ позволяет производить строго избирательную кислотную обработку (а также любой другой вид обработки) с точностью до нескольких сантиметров, определяемой точностью контроля за установкой перфоратора.

Опытное изучение давления в канале при точечной гидропескоструйной перфорации проводили на стенде $[8,9]$. Он состоит из приспособления, моделирующего канал в породе, которое заключено в кожух, регистрирующих манометров, пневматических ком- 
пенсаторов давления и насосного агрегата с системой манифольдов.

Схема приспособления, моделирующего канал в породе [10], показана на рис. 1. К основанию - 4 сваркой прикреплены толстостенный переводник - 1 и гайка - 7. В переводник ввинчен корпус насадки перфоратора - 3 с насадкой - 2. В гайку -7 ввинчен патрубок - 8 длиной 500 мм, изготовленный из 60-мм насосно-компрессорной трубы. С одной стороны патрубок закрыт заглушкой - 10, а с другой стороны он имеет втулку - 6 с резьбой. Во втулку ввинчивается штуцер - 5, моделирующий вход в канал.

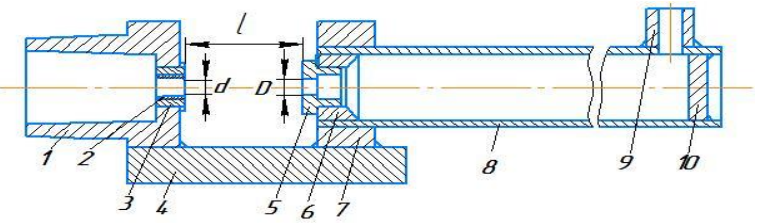

Рис. 1. Устройство, моделируюшее проиессы, происходящчие в канале

Fig. 1. Device simulating the processes occurring in the channel

На патрубке - 8 к муфте - 9 присоединяется манометр. Ось насадки совпадает с осью штуцера и патрубка. Во избежание разбрызгивания жидкости приспособление заключено в кожух. В процессе исследования применяли насадки диаметром $d_{1}=4,5$ мм и $d_{2}=6$ мм.

Так как при точечной гидропескоструйной перфорации диаметр отверстия в обсадной колонне приблизительно равен 2,5-3,0 диаметрам насадки, были взяты штуцеры диаметром $D_{1}=11,5 \mathrm{мm}, D_{2}=15$ мм и $D_{3}=22$ мм. Расстояние от насадки до входа в канал $l$ изменяли от 5 до 100 мм, вращая патрубок - 8 в гайке -7 .

Методика проведения опытов заключается в следующем. В приспособлении устанавливали насадку и штуцер определенных диаметров $-d$ и $D-$ на необходимом расстоянии между ними. Насосным агрегатом прокачивали жидкость при давлении перед насадкой $p_{1}$ и фиксировали давление внутри патрубка $p_{2}$. В опытах в качестве рабочей жидкости использовали воду и водный раствор сульфит-спиртовой барды (ССБ) с вязкостью 12,65 сПз при температуре $20^{\circ} \mathrm{C}$.

Из таблицы видно, что на исследованном участке изменения расстояния от насадки до входа в канал - 1 от 5 до 100 мм наблюдаются три характерные особенности изменения $p_{2}$ в зависимости от отношения диаметра входного отверстия в канал к диаметру насадки $D / d$. При отношении $D / d>2,55$ с увеличением $d$ давление $p_{2}$ возрастает. При $D / d<2,55$ с увеличением $d$ давление $p_{2}$ убывает. При $D / d \approx 2,55$ с увеличением $d$ давление $p_{2}$ сначала возрастает, а затем убывает.

Зависимость $p_{2}=f\left(p_{1}\right)$ всегда такова, что с увеличением $p_{1}$ увеличивается $p_{2}$. Однако характер этого изменения зависит от отношения $D / d$, что видно из следующих данных.

$$
\begin{gathered}
\frac{D}{d} \ldots 1,91 \ldots \ldots 2,5 \ldots \ldots 2,55 \ldots \ldots 3,33 \ldots \ldots 3,67 \ldots \ldots 4,88 \\
\frac{p_{2}}{200} \ldots 0,85 \ldots \ldots 0,36 \ldots \ldots 0,32 \ldots \ldots 0,094 \ldots \ldots 0,09 \ldots \ldots 0,03
\end{gathered}
$$

Следует отметить, что при проведении опытов на стенде возникли значительные затруднения при регистрации давления $p_{2}$. Несмотря на применение двух пневматических компенсаторов высокого давления и трубчатых компенсаторов, наблюдались сильные колебания давления $p_{2}$, не позволившие достаточно точно зафиксировать его среднюю величину (определенную роль в этом явлении сыграло отсутствие противодавления на выходе струи из насадки).

Как показали проведенные исследования, в канале можно получить очень высокие избыточные давления, до $31 \%$ от давления перед насадкой, которые достаточны для проведения не только избирательной кислотной обработки, но и избирательного гидроразрыва пласта. Например, при перепаде давления в насадке, равном 20,0 МПа, и диаметре 4,5 мм избыточное давление в канале может составить 6,2 МПа. Эти работы можно проводить в эксплуатационных колоннах минимальной прочности с дефектом большого диаметра, т. е. там, где даже невозможна установка пакеров [1115]. Процесс избирательной кислотной обработки состоит в следующем (рис. 2).

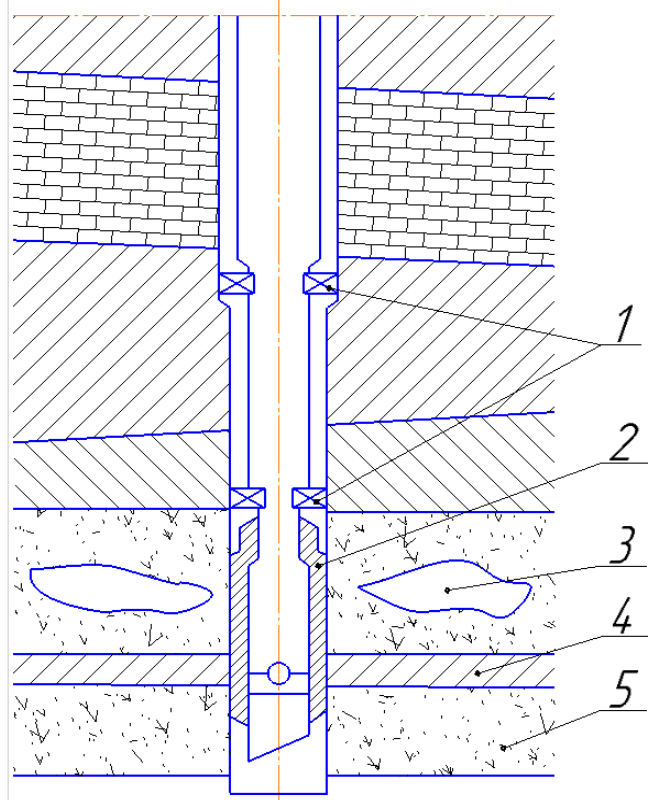

Pис. 2. Процесс избирательной кислотной обработки: 1 - фиксатор; 2 - перфоратор; 3 - канал; 4 обрабатываемый малопроничаемый участок; 5 -хорошо проницаемый пропласток

Fig. 2. Selective acid treatment: 1 - fixative; 2 - puncher; 3 - channel; 4 - processed low-permeability area; 5 -well-permeable interlayer

В скважину спускают гидропескоструйный перфоратор - 2, устанавливая его на уровне выбранного интервала обработки, и гидравлические фиксаторы, необходимые для строгого удержания перфоратора. Смещение последнего исключает возможность избирательной обработки [16-19]. Характер изменения давления в канале $p_{2}=f(l)$ в зависимости от расстояния между насадкой и входом в канал для различных отношений $D / d$ представлен в таблице. 
Таблица. Характер изменения давления в канале $p_{2}=f(l)$ в зависимости от расстояния между насадкой и входом 8 канал для различных отношений $D / d$.

Table. $\quad$ Nature of the change in pressure in the channel $p_{2}=f(l)$ depending on the distance between the nozzle and the inlet to the channel for various $D / d$ ratios

\begin{tabular}{|c|c|c|c|c|c|}
\hline $\begin{array}{c}\text { № } \\
\text { опыта } \\
\text { Experiment } \\
\text { no. }\end{array}$ & $\begin{array}{c}\text { Рабочая } \\
\text { жидкость } \\
\text { Working fluid }\end{array}$ & $\begin{array}{c}\text { Диаметр шту- } \\
\text { цера } D, \text { мм } \\
\text { Union diameter } \\
D, \mathrm{~mm}\end{array}$ & $\begin{array}{c}\text { Диаметр } \\
\text { насадки } d, \text { мм } \\
\text { Nozzle diameter } \\
d, \text { mm }\end{array}$ & $\begin{array}{l}\text { Отноше- } \\
\text { ние } D / d \\
D / d \text { ratio }\end{array}$ & $\begin{array}{l}\text { Характер зависимости } p_{2}=f(l) \\
\text { The nature of dependence } p_{2}=f(l)\end{array}$ \\
\hline 1 & Вода/Water & 11,5 & 4,5 & 2,55 & $\begin{array}{c}p_{2} \text { сначала возрастает, а затем убывает } \\
p_{2} \text { first increases and then decreases }\end{array}$ \\
\hline 2 & $<<$ & 15,0 & 4,5 & 3,33 & $\begin{array}{c}p_{2} \text { сначала убывает, а затем возрастает } \\
p_{2} \text { first decreases and then increases }\end{array}$ \\
\hline 3 & $<$ & 22,0 & 4,5 & 4,88 & $p_{2}$ убывает $/ p_{2}$ decreases \\
\hline 4 & $<$ & 15,0 & 6,0 & 2,50 & $\begin{array}{c}p_{2} \text { сначала убывает, а затем возрастает } \\
p_{2} \text { first decreases and then increases }\end{array}$ \\
\hline 5 & $<<$ & 22,0 & 6,0 & 3,67 & то же/the same \\
\hline 6 & $\begin{array}{l}\text { Раствор ССБ } \\
\text { PRS solution }\end{array}$ & 11,5 & 4,5 & 2,55 & $p_{2}$ убывает $/ p_{2}$ decreases \\
\hline 7 & $<<$ & 15,0 & 4,5 & 3,33 & $p_{2}$ возрастает $/ p_{2}$ increases \\
\hline 8 & $\ll$ & 22,0 & 4,5 & 4,88 & то же/the same \\
\hline 9 & $<<$ & 11,5 & 6,0 & 1,91 & $p_{2}$ убывает $/ p_{2}$ decreases \\
\hline 10 & $<<$ & 15,0 & 6,0 & 2,50 & то же/the same \\
\hline 11 & $<<$ & 22,0 & 6,0 & 3,67 & - \\
\hline
\end{tabular}

После обычного гидропескоструйного вскрытия и промывки скважины от песка, не изменяя положения перфоратора, в трубы прокачивают кислотный раствор, который, входя в образованный канал, фильтруется через его стенки в обрабатываемый участок пласта [20]. Часть кислоты, которая после окончания обработки скопилась в стволе скважины, продавливается в пласт продавочной жидкостью через кольцевое пространство.

Фиксатор гидравлический (ФГ) предназначен для предупреждения обрыва и снятия растягивающих напряжений в колонне труб при гидропескоструйном вскрытии, а также для фиксации при центровании перфоратора в заданном интервале обработки.

Иногда кислотные обработки оказываются безуспешными, так как призабойная зона сильно засорена. В этих случаях применяют гидрокислотный разрыв. Однако его проведение ограничивается высокими давлениями, необходимыми для продавливания кислоты через плохо проницаемую зону, или же требует специального оборудования (пакеры, якоря, устьевая арматура, насосные агрегаты высокого давления и т. д.).

Особенно значительные давления, опасные для герметичности эксплуатационной колонны, возникают в скважинах большой глубины с плотными слабопроницаемыми коллекторами. Для того чтобы давление при обработке не превосходило прочности оборудования, был внедрен метод многократной гидрокислотной обработки по следующей технологии.

Сначала фильтруемую зону очищают от песчаной пробки (если она имеется), затем насоснокомпрессорные трубы спускают до фильтра (рис. 2), а устье скважины оборудуют соответствующей арматурой, рассчитанной на высокое давление. После этого закачивают 3-4 м 3 кислотного раствора (рис. 3, a) и продавочную жидкость (рис. 3, б). Затем в насоснокомпрсссорные трубы и затрубное пространство нагнетают воздух или газ (до максимального давления в распределительной будке). В таком состоянии скважину оставляют под давлением на 20 ч (рис. 3, в), после чего скважину дренируют для извлечения продуктов реакции на поверхность. Так же проводят повторную гидрокислотную обработку призабойной зоны, и при необходимости эту операцию повторяют еще раз.

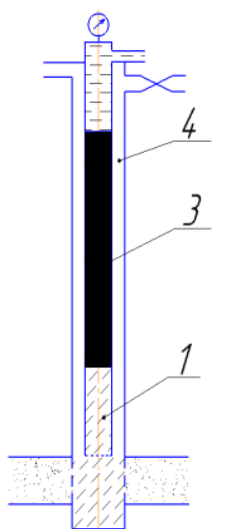

ala

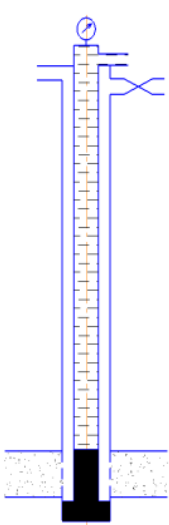

$\sigma / b$

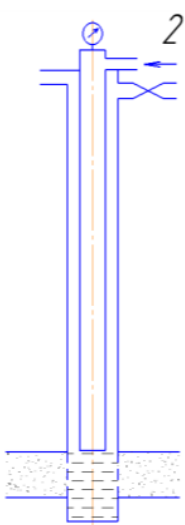

$B / c$
Pис. 3. Технологическая схема проведения одного ичикла многократной гидрокислотной обработки: 1 вода; 2 - воздух под давлением; 3 - нефть; 4 кислотный раствор; а) закачка 3-4 м $^{3}$ кислотного раствора; б) закачка продавочной жидкости; в) скважина остается под давлением на 20 ч

Fig. 3. Technological scheme of carrying out a cycle of multiple hydroacid treatment: 1 - water; 2 - air under pressure; 3 - oil; 4 - acidic solution; a) injection of 3-4 $\mathrm{m}^{3}$ of acid solution; b) injection of displacement fluid; $c$ ) the well remains under pressure for 20 hours

Из анализа результатов многократной (трехкратной) гидрокислотной обработки видно, что первоначальное давление закачки кислотного раствора после первого этапа обработки скважины было снижено на $24 \%$, а после второго - на $55 \%$. Испытания данного метода проводили на скважинах месторождения 
НГДУ «Туймазанефть» АНК Башнефть. Например, для скв 172 дебит нефти увеличился от 3,8 до 6,3 т/сут. Обычная гидрокислотная обработка не давала подобных результатов.

Часто перед закачкой кислотного раствора проводят профилактические мероприятия для уменьшения устьевого давления при обработке, одно из них мгновенное снижение давления на забое.

Эффективное проникновение кислотного раствора в пласт определяется рядом факторов, наиболее важными из которых являются:

1) время истощения кислотного раствора заданной концентрации в пластовых условиях;

2) скорость закачки его в пласт.

Необходимо отметить, что после полного истощения кислотного раствора дальнейшее проникновение его в пласт не только не приносит пользы, но даже вредно, так как истощенный раствор не расширяет, а лишь заполняет поровые каналы.

Увеличить время истощения кислотного раствора, т. е. замедлить скорость реакции, можно, добавив в раствор специальные реагенты. Так, весьма эффективным препаратом, понижающим скорость реакции,

\section{СПИСОК ЛИТЕРАТУРЫ}

1. Нефтяные залежи в карбонатных отложениях фаменского яруса самарской области: история открытия и перспективь поиска / Г.Г. Гилаев, А.Э. Манасян, Г.Д. Федорченко, В.А. Колесников, И.А. Кологреев // Нефтяное хозяйство. 2013. - № 10. - C. 38-40.

2. Zhang H., Liang Y., Zhou X. Sensitivity analysis and optima operation control for large-scale water flooding pipeline network of oilfield // Journal of petroleum science and engineering. 2017. - V. 154. - P. 38-48.

3. Khabibullin M.Ya., Suleimanov R.I. Selection of optimal design of a universal device for nonstationary pulse pumping of liquid in a reservoir pressure maintenance system // Chemical and Petroleum Engineering. - 2018. - V. 54. - Iss. 3-4. - P. 225-232. DOI: $10.1007 / \mathrm{s} 10556-018-0467-2$

4. Эффективность кислотных обработок нагнетательных скважин / К.Ш. Ямалетдинова, А.Ш. Халадов, Ю.В. Дудников, А.А. Ямалетдинова, А.Р. Габдуллин // Успехи современного естествознания. - 2017. - № 12. - С. 278-283. URL: http://www.natural-sciences.ru/ru/article/view?id=36642 （дата обращения: 24.12.2020)

5. Кислотная обработка призабойной зоны пласта баженовской свиты после проведения гидроразрыва пласта / В.Т. Литвин, К.В. Стрижнев, Т.Н. Шевчук, П.В. Рощин // Нефтяное хозяйство. - 2018. - № 4. - С. 70-73.

6. Meirmanov A., Nekrasova I. Mathematical models of a hydraulic shock // Journal of mathematical analysis and applications. - 2013. - V. 408. - Iss. 1. - P. 76-90.

7. Studying heat-affected zone deformations of electric arc welding / R.I. Suleimanov, L.Z. Zainagalina, M.Y. Khabibullin, L.M. Zaripova, N.O. Kovalev // IOP Conference Series: Materials Science and Engineering. - 2018. - P. 032053. DOI: 10.1088/1757-899X/327/3/032053.

8. Кислотные обработки: составы, механизмы реакций, дизайн В.Н. Глущенко, О.А. Пташко, Р.Я. Харисов, А.В. Денисова. Уфа: Гилем, 2010. - 392 с

9. Kadochnikova L.M., Pichugin O.N., Chebakov A.A. Analytical technique for gel treatment prediction of production and injection wells in a stratified reservoir // Iranian Journal of Science \& Technology. - 2002. - Transaction B. - V. 26. B2. - P. 205-216.

10. Zaichenko A.Yu., Glazov S.V., Salgansky E.A. Filtration combustion of viscous hydrocarbon liquids // Theoretical foundations of chemical engineering. - 2017. - V. 51. - Iss. 5. P. 673-679. является синтанол ДС-10 ТУ 2483-016-71150986-2012 (представляет собой неионогенный ПАВ и предназначен для применения в качестве эффективного поверхностно-активного вещества). Добавка его в количестве $0,5 \%$ (по весу от объема раствора) может снизить скорость реакции в 2,7 раза.

Увеличить же скорость закачки кислотного раствора в сильно дренированные пласты малодебитных скважин (до 5-10 т/сутки жидкости) с низким пластовым давлением значительно сложнее из-за недостаточной мощности применяемых кислотных агрегатов.

\section{Заключение}

Применение метода кислотной обработки с дополнительной точной перфорацией призабойной зоны эксплуатационных скважин позволяет более эффективнее проводить процесс. В результате увеличивается объем притока пластовой жидкости из пласта в скважину на $20 \ldots 30$ \% в сравнении с обычным кислотным воздействием. Причем предлагаемый метод интенсификации добычи пластовой жидкости не предполагает использования значительных дополнительных материальных затрат.

11. The application of X-ray Micro Computed Tomography (MicroCT) of core sample for estimation of physicochemical treatment efficiency / M.S. Orlov, P.V. Roschin, I.A. Struchkov, V.T. Litvin // SPE Russian Petroleum Technology Conference. Moscow, Russia, 2015. SPE-176600-MS. DOI: 10.2118/176600-MS

12. Коннов Ю.Д., Сидоркин Д.И., Хабибуллин М.Я. Механизация технологического процесса спуско-подъемных операций при текущем и капитальном ремонте скважин // Научные труды НИПИ Нефтегаз ГНКАР. - 2018. - № 2. - С. 15-24. DOI: $10.5510 / 0 G P 20180200346$

13. Assem A.I., Nasr-El-Din H.A., De Wolf C.A. Formation damage due to iron precipitation in carbonate rocks // SPE European Formation Damage Conference \& Exhibition. - 2013. URL: http:// dx.doi.org/10.2118/165203-MS (дата обращения: 24.12.2020).

14. Wenyue S., Mun-Hong H. Forecasting and uncertainty quantification for naturally fractured reservoirs using a new dataspace inversion procedure // 15th Conference on the Mathematics of Oil Recovery (ECMOR). - Amsterdam, Netherlands: European Assoc. Geoscientists \& Engineers Computational geosciences, 2017. - V. 21. - Iss. 5-6. P. 1443-1458.

15. Abdyukova R.Y. Studies on operation and types of drilling pump valves // IOP Conference Series: Materials Science and Engineering. - 2019. - P. 012050. DOI: 10.1088/1757899X/560/1/012050

16. Rady A. Iron precipitation in calcite, dolomite and sandstone cores // SPE Russian Petroleum Technology Conference. - 2015. URL: http://dx.doi.org/10.2118/176574-MS (дата обращения: 24.12.2020)

17. Rabie A.I. Sodium gluconate as a new environmentally friendly iron-controlling agent for $\mathrm{HP} / \mathrm{HT}$ acidizing treatments // SPE Middle East Oil \& Gas Show and Conference. - 2015. URL: http://dx.doi.org/10.2118/172640-MS (дата обращения: 24.12.2020).

18. Литвин В.Т., Стрижнев К.В., Рощин П.В. Особенности строения и интенсификации притоков нефти в сложных коллекторах баженовской свиты Пальяновского месторождения // Нефтегазовая геология. Теория и практика. - 2015. T. 10. - № 3. URL: http://www.ngtp.ru/rub/11/36_2015.pdf (дата обращения: 24.12.2020).

19. Гилаев Ген.Г., Хабибуллин М.Я., Гилаев Г.Г. Перспективы применения кислотного геля для закачки проппанта в процессе проведения гидроразрыва карбонатных пластов на 
территории самарской области // Нефтяное хозяйство. 2020. - № 8. - C. 54-57.

20. Nsoga V.N., Hona J., Pemha E. Numerical simulation of heat distribution with temperature-dependent thermal conductivity in a two-dimensional liquid flow // International Journal of nonlinear sciences and numerical simulation. - 2017. - V. 18. Iss. 6. - P. 507-513.

Поступила 13.01.2021 2.

\section{Информация об авторах}

Хабибуллин М.Я., кандидат технических наук, доцент кафедры нефтепромысловых машин и оборудования, Уфимский государственный нефтяной технический университет, филиал в г. Октябрьский.

Гилаев Г.Г., доктор технических наук, профессор кафедры нефтегазового дела, Кубанский государственный технологический университет, Институт нефти, газа и энергетики. 
UDC 622.279 .72

\title{
INCREASING THE EFFICIENCY OF WELL SELECTIVE ACID TREATMENT BY APPLYING PRECISION HYDRO-SAND BLASTING
}

\author{
Marat Ya. Khabibullin', \\ m-hab@mail.ru \\ Gani G. Gilaev², \\ gggilaev@gmail.com \\ 1 Ufa State Petroleum Technical University, branch in Oktyabrsky, \\ 54 a, Devonskaya street, Oktyabrsky, 452607, Russia. \\ 2 Kuban State Technological University, \\ 88, Starokubanskaya street, Krasnodar, 350058, Russia.
}

The relevance of the study is caused by the need to ensure the point distribution of acid solution during acid treatment of the bottomhole zone of the production well. Using this method, the efficiency of this process increases by deeper dissolution of limestone rock in the bottomhole zone of the well and thereby completely opening channels for the flow of formation fluid from the formation into the well. The aim of the research is to develop and propose a method of point hydrosand-jet perforation during acid treatment of the bottomhole zone of a production well, a methodology for its application, and to create designs for underground and surface equipment of wells for implementing the developed method.

Objects: laboratory stand with a device simulating a channel in the rock; hydrosand-jet perforator for hydrosand-jet opening; clamp designed to prevent breakage and relieve tensile stresses in the pipe string during hydrosand-jet opening and for fixing when centering the perforator in a given processing interval; acid solution based on hydrochloric acid with a volume of 3-4 $\mathrm{m}^{3}$; displacement fluid.

Methods. The experimental study of the pressure in the channel at point hydrosand-jet perforation was carried out on a stand. In the device, a nozzle and a fitting of certain diameters $-d$ and $D$ - were installed at the required distance between them. The pumping unit was used to pump the liquid at a pressure $p_{1}$ before the attachment, and the pressure inside the branch pipe $p_{2}$ was recorded. In the experiments, water and aqueous solution of sulfite-alcohol stillage with a viscosity of $12,65 \mathrm{cPz}$ at $20^{\circ} \mathrm{C}$ were used as the working fluid. The selective acidizing consists in the fact that a hydroseed-jet perforator is lowered into the well, set at the level of the selected treatment interval, and hydraulic clamps necessary to strictly hold the perforator. After that 3-4 $\mathrm{m}^{3}$ of acid solution and squeezing fluid are pumped in. Then, air or gas is injected into the tubing and the annular space (up to the maximum pressure in the distribution booth) and in this state the well is left under pressure for 20 hours and at the end the well is drained to extract the reaction products to the surface.

Results. From the analysis of the results of multiple (threefold) hydro-acid treatment, it can be seen that the initial injection pressure of the acid solution after the first stage of the well treatment was reduced by $24 \%$, and after the second - by $55 \%$. The acidizing method with additional accurate perforation of the bottomhole zone of production wells allows implementing a more efficient treatment. As a result, the volume of formation fluid inflow from the formation into the well increases by $20 . . .30 \%$ in comparison with conventional acidizing.

Key words:

Channel, filtration, speed, reaction, synthanol, reagent, opening.

\section{REFERENCES}

1. Gilaev G.G., Manasyan A.E., Fedorchenko G.D., Kolesnikov V.A., Kologreev I.A. Oil deposits in the carbonate deposits of the Famennian stage of the Samara region: the history of discovery and prospects of search. Oil industry, 2013, no. 10, pp. 38-40. In Rus.

2. Zhang H., Liang Y., Zhou X. Sensitivity analysis and optimal operation control for large-scale waterflooding pipeline network of oilfield. Journal of petroleum science and engineering, 2017, vol. 154 , pp. 38-48.

3. Khabibullin M.Ya., Suleimanov R.I. Selection of optimal design of a universal device for nonstationary pulse pumping of liquid in a reservoir pressure maintenance system. Chemical and Petroleum Engineering, 2018, vol. 54, Iss. 3-4, pp. 225-232. DOI: 10.1007/s10556-018-0467-2

4. Yamaletdinova K.Sh., Khaladov A.Sh., Dudnikov Yu.V., Yamaletdinova A.A., Gabdullin A.R. The effectiveness of acid treatments for injection wells. Successes modern science, 2017, no. 12, pp. 278-283. In Rus. Available at: http://www.natural-sciences. ru/ru/article/ view?id=36642 (accessed: 24 December 2020).

5. Litvin V.T., Strizhnev K.V., Shevchuk T.N., Roshchin P.V. Acid treatment bottomhole formation zone of the Bazhenov formation after hydraulic fracturing layer. Oil industry, 2018, no. 4, pp. 70-73. In Rus.

6. Meirmanov A., Nekrasova I. Mathematical models of a hydraulic shock. Journal of mathematical analysis and applications, 2013, vol. 408, Iss. 1, pp. 76-90.
7. Suleimanov R.I., Zainagalina L.Z., Khabibullin M.Y., Zaripova L.M., Kovalev N.O. Studying heat-affected zone deformations of electric arc welding. IOP Conference Series: Materials Science and Engineering, 2018, p. 032053. DOI: 10.1088/1757899X/327/3/032053.

8. Glushchenko V.N., Ptashko O.A., Kharisov R.Ya., Denisova A.V. Kislotnye obrabotki: sostavy, mekhanizmy reaktsiy, disayn [Acid treatments: compositions, reaction mechanisms, design]. Ufa, Guillem Publ., 2010. 392 p

9. Kadochnikova L.M., Pichugin O.N., Chebakov A.A. Analytical technique for gel treatment prediction of production and injection wells in a stratified reservoir. Iranian Journal of Science \& Technology, 2002, Transaction B, vol. 26, B2, pp. 205-216.

10. Zaichenko A.Yu., Glazov S.V., Salgansky E.A. Filtration combustion of viscous hydrocarbon liquids. Theoretical foundations of chemical engineering, 2017, vol. 51, Iss. 5, pp. 673-679.

11. Orlov M.S., Roschin P.V., Struchkov I.A., Litvin V.T. The application of X-ray Micro Computed Tomography (Micro-CT) of core sample for estimation of physicochemical treatment efficiency. SPE Russian Petroleum Technology Conference. Moscow, Russia, 2015. SPE-176600-MS. DOI: 10.2118/176600-MS.

12. Konnov Yu.D., Sidorkin D.I., Khabibullin M.Ya. Mechanization of the technological process of tripping and lifting operations during routine and overhaul of wells. Scientific works of NIPI Neftegaz SOCAR, 2018, no. 2, pp. 15-24. In Rus. DOI: $10.5510 /$ OGP20180200346. 
13. Assem A.I., Nasr-El-Din H.A., De Wolf C.A. Formation damage due to iron precipitation in carbonate rocks. SPE European For mation Damage Conference \& Exhibition, 2013. Available at: http://dx.doi.org/10.2118/165203-MS (accessed: 24 Decembe 2020)

14. Wenyue S., Mun-Hong H. Forecasting and uncertainty quantification for naturally fractured reservoirs using a new data-space inversion procedure. $15^{\text {th }}$ Conference on the Mathematics of Oil Recovery (ECMOR). Amsterdam, Netherlands, European Assoc. Geoscientists \& Engineers Computational geosciences, 2017. Vol. 21, Iss. 5-6, pp. 1443-1458.

15. Abdyukova R.Y. Studies on operation and types of drilling pump valves. IOP Conference Series: Materials Science and Engineering, 2019, pp. 012050. DOI: 10.1088/1757-899X/560/1/012050.

16. Rady A. Iron precipitation in calcite, dolomite and sandstone cores. SPE Russian Petroleum Technology Conference. 2015. Available at: http://dx.doi.org/10.2118/176574-MS (accessed: 24 December 2020)

17. Rabie A.I. Sodium gluconate as a new environmentally friendly iron-controlling agent for HP/HT acidizing treatments. SPE Mid-

\section{Information about the authors}

Marat Ya. Khabibullin, Cand. Sc., associate professor, Ufa State Petroleum Technical University, branch in Oktyabrsky.

Gani G. Gilaev, Dr. Sc., professor, Kuban State Technological University. dle East Oil \& Gas Show and Conference. 2015. Available at: http://dx.doi.org/10.2118/172640-MS (accessed: 24 December 2020)

18. Litvin V.T., Strizhnev K.V., Roshchin P.V. Features of the structure and intensification oil inflows in complex reservoirs of the Bazhenov formation of the Palyanovsky deposits. Oil and gas geology. Theory and practice, 2015, vol. 10, no. 3. In Rus. Available at: http://www.ngtp.ru/rub/11/36_2015.pdf (accessed: 24 December 2020)

19. Gilaev Gen.G., Khabibullin M.Ya., Gilaev G.G. Prospects for using acid gel for pumping proppant in the process of hydraulic fracturing of carbonate reservoirs in the Samara region. Oil industry, 2020, no. 8, pp. 54-57. In Rus.

20. Nsoga V.N., Hona J., Pemha E. Numerical simulation of heat distrimensional liquid flow. International Journal of nonlinear sciences and numerical simulation, 2017, vol. 18, Iss. 6, pp. 507-513.

Received: 13 January 2021. bution with temperature-dependent thermal conductivity in a twodi- 